\title{
Schooling Interrupted: Educating Children and Youth in the Covid-19 Era
}

LORIN W. ANDERSON ${ }^{1}$

$\approx$ Distance education has been practised for generations, although its purpose and form have changed. Correspondence courses, in which students receive instruction via mail and respond with assignments or questions to the instructor, date back to the mid-18oos, if not earlier. As technology changed, so did the nature of distance education. Radio, television, computers, and, most recently, the internet have supported distance education over the years.

Research studies on the use and effectiveness of distance education focus almost exclusively on higher education. A recent research synthesis suggests that fewer than five per cent of the studies have addressed K-12 education. The Covid-19 pandemic, however, has brought distance education into K-12 schools and classrooms. Distance education in the Covid-19 era has been referred to as 'emergency remote teaching' (ERT) because, with little research on which to rely, teachers must improvise quick solutions under less-than-ideal circumstances, a situation that causes many teachers to experience stress.

The purpose of this paper is to address five fundamental questions. First, what problems have K-12 school administrators and teachers faced in implementing ERT? Second, under what conditions has ERT been effective since the advent of the Covid-19 pandemic? Third, what are the strengths of ERT in K-12 schools and classrooms? Fourth, what are the weaknesses of ERT in K-12 schools and classrooms? Fifth, to what extent will lessons learned from ERT influence teaching and learning when the pandemic abates? The paper concludes with a brief set of recommendations. Throughout the paper, the focus is on $\mathrm{K}-12$ education.

Keywords: effect of Covid-19 on children and youth, emergency remote teaching, implementation problems, improving remote teaching and learning, reimagining schooling

1 Professor Emeritus at the University of South Carolina, United States of America; anderson.lorinw@gmail.com. 


\section{Prekinjeno šolanje: izobraževanje otrok in mladih v dobi covida-19}

LORIN W. ANDERSON

$\propto$ Izobraževanje na daljavo se izvaja že več generacij, čeprav sta se njegov namen in oblika spremenila. Korespondenčni tečaji, pri katerih učenci prejemajo navodila po pošti in odgovarjajo $\mathrm{z}$ nalogami ali vprašanji inštruktorju, segajo v sredino 19. stoletja, če ne še bolj v preteklost. S spreminjanjem tehnologije se je spreminjal tudi način izobraževanja na daljavo. Radio, televizija, računalniki in v zadnjem času tudi svetovni splet so z leti podprli izobraževanje na daljavo. Raziskovalne študije o uporabi in učinkovitosti izobraževanja na daljavo se skoraj izključno osredinjajo na visokošolsko izobraževanje. Nedavna sinteza raziskav kaže, da je manj kot pet odstotkov študij obravnavalo t. i. izobraževanje K-12. Zaradi pandemije covida-19 je izobraževanje na daljavo začelo potekati tudi v šolah in učilnicah K-12. Izobraževanje na daljavo med pandemijo covida-19 se imenuje "poučevanje na daljavo v izrednih razmerah", saj morajo učitelji zaradi pomanjkanja raziskav, na katere bi se lahko oprli, najti hitre rešitve v kar se da neidealnih okoliščinah, kar pri veliko učiteljih povzroča stres. Namen prispevka je odgovoriti na pet temeljnih vprašanj, tj.: s katerimi težavami so se pri izvajanju poučevanja na daljavo v izrednih razmerah srečevali ravnatelji in učitelji; v kakšnih pogojih je bilo poučevanje na daljavo v izrednih razmerah učinkovito od začetka pojava pandemije covida-19; katere so prednosti poučevanja na daljavo v izrednih razmerah v šolah in razredih K-12; katere so slabosti poučevanja na daljavo $\mathrm{v}$ izrednih razmerah $\mathrm{v}$ šolah in razredih K-12; $\mathrm{v}$ kolikšni meri bodo izkušnje, pridobljene pri poučevanju na daljavo v izrednih razmerah, vplivale na poučevanje in učenje, ko se bo pandemija umirila. Prispevek se konča s kratkimi priporočili. V celotnem prispevku je poudarek na izobraževanju K-12.

Ključne besede: učinek covida-19 na otroke in mlade, poučevanje na daljavo v izrednih razmerah, težave pri izvajanju, izboljšanje poučevanja in učenja na daljavo, redefinicija šolstva 


\section{Introduction}

Distance education has been practised for generations, although its form and purpose have changed over the years. Correspondence courses, in which students receive instruction via mail and respond with assignments or questions to the instructor, date back to the mid-18oos. In the United States in the 1920 s and 1930s, radio became a natural medium for extension courses offered to farmers through state agricultural colleges. In the 1950 and 1960s, television supplemented, and sometimes replaced, radio in delivering distance education. By the mid-1970s, personal computers became the darlings of distance education delivery. Internet access, an extension of the scope of personal computers, is now the preferred form of distance education. More recently, the phrase 'remote learning' has replaced the phrase 'distance education.'

Until approximately 2020, systematic study of the use and effectiveness of distance education has focused almost exclusively on higher education. A recent research synthesis suggests that fewer than five per cent of the studies have addressed K-12 education. However, the Covid-19 pandemic (hereafter 'the pandemic') has brought distance education into elementary and secondary schools. Henrietta Fore, executive director of UNICEF, has suggested that the pandemic has created a 'global education emergency' (Hess, 2021). Hodges et al. (2020) refer to distance education in the Covid-19 era as 'emergency remote teaching' (ERT): the rapidity with which the pandemic descended required teachers to improvise quick solutions under less-than-ideal circumstances with little if any research or previous practice on which to rely.

At the pandemic's peak, 1.5 billion students in 188 countries were locked out of their schools (OECD, 2021). In OECD countries, the average length of school closure was seventy days, with considerable variation across countries. Importantly, school closures were longer in countries where students had lower levels of academic performance.

Most countries have made heroic efforts to find ways to deliver instruction during this lockout, many involving some form of remote teaching. The purpose of this paper is to address five fundamental questions. First, what problems have K-12 school administrators and teachers faced in implementing ERT? Second, under what conditions has ERT been effective since the advent of the Covid-19 pandemic? Third, what are the strengths of ERT in K-12 schools and classrooms? Fourth, what are the weaknesses of ERT in K-12 schools and classrooms? Fifth, to what extent will lessons learned from ERT influence teaching and learning when the pandemic abates? The paper concludes with a brief set of recommendations. Throughout the paper, the focus is on K-12 education. 


\section{Method}

Because the Covid-19 pandemic began sometime in March 2020, the search for relevant studies and commentary focused on Google Scholar and Google. Search terms included 'Covid-19 and education', 'the impact of Covid-19 on education,' and 'educational accommodations in the Covid-19 era.' Except for a large-scale study conducted jointly by UNESCO, UNICEF, and the World Bank and a meta-analysis conducted by Harry Patrinos from the World Bank, no other multi-national studies were found. Most studies were small and focused on specific jurisdictions (e.g., localities, states, regions). Many of the articles were anecdotal as educators struggled with the changes needed because of the pandemic.

In the interim between the submission of the original manuscript and the submission of the revision of the manuscript, three publications addressing multi-national issues and/or containing multi-national data were located. The first was an update of the UNESCO, UNICEF, and World Bank study, published under the auspices of the OECD. The second was a publication of Save the Children International, which presented survey data from parents, caregivers, and students in 46 countries. The third was a volume edited by Fernando Reimers of Harvard University containing chapters written by educators in thirteen countries. Interesting and importantly, these three sources provided additional data and insights but did not fundamentally change the answers to the five research questions.

\section{Delivering Remote Learning}

Once schools were shuttered, educators and legislators had to decide how best to deliver instruction to students. Results from various surveys, both national and international, suggested that, initially, four primary modes of instruction were in place: take-home materials, radio, television, and online platforms. Without computers (or tablets or smartphones) and online connectivity, online platforms are not an option for schools. As expected, then, only two-thirds of schools in low-income countries reported using online platforms, in contrast with 90 to 95 per cent of schools in middle- and high-income countries (UNESCO, UNICEF, and the World Bank, 2020). In Sub-Saharan Africa, $45 \%$ of children had no exposure at all to remote learning. Of those who did, it was mostly radio, TV, or written materials. In Latin America, 90\% of children received some remote learning, but less than one-half was through the internet. The rest was through radio and/or TV. 
The perceived effectiveness of remote learning varies by modality and income group. Globally, online learning platforms were rated as very effective (36\%) or fairly effective (58\%), particularly among high- and upper-middle-income countries. None of the high-income and only six per cent of upper-middle-income countries rated online learning as ineffective. In low-income countries, take-home instructional materials were rated the least effective among the four modes of instruction (with Ministries of Education in $43 \%$ of those countries rating them as 'not effective'). For middle-income and high-income countries, radio received the lowest effectiveness ratings (with between onefourth and one-third of the countries rating radio as 'not effective').

As schools have begun to reopen, hybrid modes of instruction have been appearing. In the United States, three modes of instruction are reportedly being used: fully remote ( $60 \%$ of $\mathrm{K}-12$ students), hybrid $(20 \%)$, and fully in-person $(20 \%)$. A rather typical example of the hybrid mode is attending in-person classes twice a week and remote classes three times a week. For example, half of the students might attend classes in-person on Monday and Tuesday, while the other half would attend classes in-person on Thursday and Friday. Wednesdays are reserved for deep cleaning of each classroom. The division of classes into two groups of students makes it possible to maintain appropriate social distancing within the classroom.

In many states, the decision to return to in-person instruction has not been an easy one. For example, a survey of students and parents in the Chicago, Illinois, public schools conducted in December 2020, suggested that only $37 \%$ of students would return to schools if they were reopened for the spring term. In Mississippi, home-schooling by parents has increased by $35 \%$ in one year, largely because of parents' disappointment with the remote learning provided by the schools. In some cases, the decision to reopen schools has pitted teachers against parents and government officials. In the state of Florida, for example, the teachers' union has sued the governor over the state's efforts to require schools to return to total in-person instruction. The argument is that teachers should not be forced to go back to their classrooms unless they are completely safe (Goldstein \& Shapiro, 2020). In contrast, in North Carolina, a group of parents has sued the local education authority claiming that virtual learning is less effective than in-person learning, thus violating the state's constitution that guarantees students should have an equal opportunity to quality education. Another factor in the parents' lawsuit is that many of them struggle to balance work and childcare while overseeing remote learning (NY Times, 2020).

So, where are we? First, the concept of remote learning is not homogeneous. There are multiple modes of delivering instruction remotely. Second, 
because online learning requires technological hardware and internet connectivity, reliance on online learning is likely to discriminate against poor communities and poor countries. In many ways, the pandemic has simply magnified the 'digital divide' that widens inequalities among the 'haves' and the 'have nots.' Third, whether and when to reopen schools is an issue that will likely engender emotion-laden discussions that incorporate concerns for the safety of teachers and students, the social-emotional development of students (particularly younger students), and parents' abilities to balance childcare with work demands.

\section{Effect of Covid-19 on Children and Youth}

There is a great deal of anecdotal evidence that the pandemic has profoundly affected education worldwide (Reimers, 2021). We should not be surprised, then, that closing schools has affected children and youth in many ways. Somewhat surprising, however, is that the effect is quite complex.

With respect to the effect on academic learning, numerous articles have been written about the so-called 'Covid slide' (Bielinski et al., 2020; Donnelly \& Patrinos, 2020) and 'learning loss' (Dorn et al., 2020). In addition, Kuhfeld et al. (2020) have argued that there is a consensus among researchers that school closings during the pandemic have negatively affected student learning. Unfortunately, this assertation masks the complexity of school closings' impact on student learning.

One problem in understanding this impact is there are two quite different definitions of 'learning loss.' For example, Henrietta Fore, executive director of UNICEF, has argued that a major concern for her agency is the amount that children forget when not in school (cited in Hess, 2021). Similarly, Donnelly and Patrinos (2020) concluded that Kazakhstanian students had experienced a significant reduction in existing knowledge. Both assertions imply that students now know less than they did at the beginning of the pandemic.

In contrast, Beth Tarasawa, vice president for research at NWEA, has suggested that the results of a large-scale NWEA study indicate that students kept learning in virtual environments, but they learned less than would be expected based on prior year's data (as quoted in Turner, 2020). Similarly, Dorn, et al (2020) compared the increases in student scores between fall 2019 and fall 2020 with prior fall-to-fall gain scores over a three-year period Learning less than expected is quite different from students forgetting what they have learned. As we shall see, these two different definitions lead to quite different decisions about how to solve the problem of learning loss. 
Next, there is the matter of the questionable validity of the data. Because of increased student attrition during the pandemic, the two populations used to compute learning loss are quite different. Specifically, a sizable number of the most vulnerable students (e.g., ethnic and racial minorities, poor children and youth) were not assessed in the most recent round of testing; hence, their achievement is not reflected in the data. One clear implication is that the impact of the pandemic on student achievement is likely underestimated (Kuhfeld et al., 2020).

Speaking of vulnerability, virtually every study conducted in the past six months has found that the effect of the pandemic on vulnerable children and youth is much greater than on more well-to-do children (Adams, 2021; Dorn et al., 2020; Korman et al., 2020; Kufeld et al., 2020; Saavedra, 2021). In addition to poor and racial and ethnic minority children, vulnerable students include children with disabilities, children in foster care, homeless children, and migrants. Gender inequity is another often neglected component of vulnerability (Reimers, 2021). As Fore (cited in Hess, 2020) has stated, many girls will never return to school in communities where girls are expected to take care of family members. Furthermore, one of the lessons learned from the Ebola Crisis of 2015 was that the closure of schools led to an increased risk of sexual exploitation, early pregnancy, and early and forced marriage (Giannini \& Albrectsen, 2020).

The results of multiple studies suggest that the effect of the pandemic is greater in mathematics than in reading (Bielinski et al., 2020; Getchell, 2020 ). Based on these studies learning gains in reading are $63 \%$ to $68 \%$ of what they normally are on average; learning gains in mathematics are much lower at only $37 \%$ to $50 \%$ of the average normal school year gains (Kuhfeld \& Tarasawa, 2020). The available data, then, suggest that students will have lost the equivalent of three months of learning in mathematics and one-and-a-half months of learning in reading. To make matters worse, the negative impact on mathematics achievement increases across grade levels, K-5 (Dorn et al., 2020). One exception to this generalisation is a large-scale study conducted in India where the loss in language was greater than the loss in mathematics, although the loss in both subjects was staggering (92\% and 82\%, respectively) (Research Group, Azim Premji Foundation, 2021).

To complicate matters further, obtaining valid and reliable data for the youngest students is quite problematic, particularly when tested remotely. Children in Grades 1 and 2 who were tested remotely in fall 2020 showed large improvements in their percentile rank since fall 2019; while those tested in-person showed patterns more consistent with those of older students (where percentiles stayed the same or decreased (Kuhfeld et al., 2020). These findings suggest 
that remote testing may be a qualitatively different experience for the youngest students. One reasonable explanation for this difference between in-person and remote testing results is that parents may be assisting their children on the remote tests (Ferguson, 2020).

The data on the effect of the pandemic on students' mental health are equally, if not more, complex. The titles of two of the cited articles summarise the opposite positions quite nicely: 'In a world "so upside down," the virus in taking a toll on young people's mental health' (Levin, 2020, title); 'Survey reveals children coped well with school closure' (Gray, 2020, title). More has been written about the negative impacts of the pandemic on mental health, describing rising rates of depression, anxiety (Dorn et al., 2020), psychological distress (Ritz et al., 2020), and disengagement (Ferguson, 2020). If you read through the various articles, however, you arrive at two conclusions. First, some students are doing quite well with virtual learning; many are not. Second, those who are not doing well tend to be those who have not done well in in-person classrooms (Christakis, 2020).

The problem facing educators, then, is to differentiate these two groups of students and provide the kind of support and encouragement they need to be successful. To this end, Belinda Ludlam, an assistant headteacher and head of teaching and learning at a large academy in Hampshire, UK, has identified five types of learners based on her experience.

1. These students made their usual progress and revealed no issues. They found a good balance between schoolwork, relaxation, sports, and hobbies during school closure.

2. These students enjoyed not being at school but needed teachers and peers around them to ask or advise them about their work.

3. These students switched off, figurately and literally. They were not worried about school, did little work, and did not have family members urging them to do anything. They did not respond to emails or other digital communications.

4. These students were emotionally affected by not being at school. Without friends and teachers, they were less able to concentrate and did not always complete their work. They were also worried about the pandemic and anxious about its impact on their family.

5. These students were overwhelmed technologically. These barriers came in many forms, with some students trying to access all work on their phones or sharing a single laptop with siblings or parents. Equally, poor-quality broadband connection or limited bandwidth was an issue for some. 
One might predict that students in Category 1 are 'coping well', whereas those in Category 4 are more likely to be anxious and depressed. Within Ludlam's framework, then, the overall picture of students' mental health depends on the percentage of students in each of her categories. The results of a multi-national survey conducted by Save the Children suggested that $83 \%$ of children and $89 \%$ of parents reported an increase in negative feelings due to the pandemic (Ritz et al., 2020). In contrast, a survey of more than 4,000 students in Great Britain found that only about one-third of the students reported experiencing greater sadness, stress, and worry after the shuttering of the schools (Khan, 2020). What we seem to have here is a bipolar distribution.

There is one area in which there seems to be some general agreement: social development (Beane \& Shearer, 2020). Surveys of primary and elementary school children and their parents have found that between 40 and 65 per cent of children are feeling increasingly lonely. Dodd, Lester, and Cartwright-Hatton (2020) estimate that this is an increase of around 40 to 50 per cent compared to previous levels. Ritzet al. (2020) compared their survey results for two groups of children. One group consisted of children who had little (if any) contact with friends; the other group contained children who regularly interacted with their friends. For the first group, 57\% were less happy, and 54\% were more worried. In contrast, for the second group, less than $5 \%$ reported similar feelings. The lack of opportunities for social development is particularly problematic for young school-aged children, ages 5 through 7.

\section{Problems with Remote Schooling}

Many of the problems associated with remote schooling are merely exacerbations of problems with in-person schooling (Christakis, 2020). This section will focus on three problems associated with remote schooling: the digital divide, disengagement, and cheating.

\section{The Digital Divide}

The so-called 'digital divide' (Junio, 2020; van Dyjk, 2020) is a problem primarily because online learning is the gold standard of remote learning for several reasons. First, online learning is the most interactive of all technologies (i.e., radio, television, written materials, stand-alone computers). Second, online learning provides students with access to a myriad of support software, including learning management platforms (e.g., Canvas, Google Classroom, Kami), communication platforms (e.g., ClassDojo), and content and lesson 
delivery platforms (e.g., edpuzzle, SharePlus, and Zearn Math). Third, in the United States and several other countries students are expected to rely on the internet at home to complete and submit assignments (Auxier \& Anderson, 2020). In this regard, Lake and Makori (2020) found that two of every five students surveyed had to do their schoolwork on cell phones and use public WiFi to access the internet, putting them at a distinct disadvantage. Finally, and perhaps most importantly, digital inequality reinforces existing social and economic inequality (van Dijk, 2020).

How large is the digital divide in education? In the United States, 35\% of lower-income households do not have a high-speed internet connection, in contrast with $6 \%$ of upper-income households (Auxier \& Anderson, 2020). Among UNESCO member countries, $64 \%$ of low-income countries use online platforms compared to 90 to $95 \%$ of middle- and high-income countries (UNESCO, UNICEF, and the World Bank, 2020). In Sub-Saharan Africa, internet access is less than 5 per cent (Asim et al., 2020).

Before moving on, it is important to make one final point. The digital divide is not just about whether students have devices and can connect to the internet. Students whose parents lack the skills or time to help them use the online platform and troubleshoot when needed are also at risk of falling behind.

\section{Disengagement}

In her excellent book, The path to dropping out, Melissa Roderick (1993) argues that the act of dropping out of school is the culmination of a process of disengagement, beginning with simply not attending. In the Covid-19 era, there is ample evidence that student attendance has decreased (CTV News, 2021). Korman et al. (2020) have labelled this decrease an 'attendance crisis.' Across multiple studies, the estimated decrease in attendance ranges from 15 to 20 per cent, about twice that before schools were closed (Lieberman, 2020). However, the reliability of these data is somewhat suspect since there is no common definition of what it means to be present when schooling is virtual (Kamenetz, 2020). In addition, there are numerous anecdotal reports of students logging into virtual classrooms and then walking away from their computers. These students are likely to be counted as present, not absent (Kamentz, 2020).

If attendance is declining and many students are having difficulty submitting assignments (as mentioned above), it should not be surprising that the grades or marks students receive are also declining. Available data suggest that the percentage of students receiving grades of $\mathrm{F}$, on average, has increased dramatically, ranging from increases of 40 to 80 per cent. Unfortunately, but not 
unexpectedly, the increase in F grades is much higher for economically disadvantaged and minority students, approaching 400 per cent (Tomkins, 2020).

\section{Cheating}

Although the prevalence of cheating remains elusive, no one doubts that the opportunity for it in virtual schooling is great. With respect to prevalence, some data exist. For example, a study by visualobjects.com revealed that $52 \%$ of students anticipated widespread cheating and breaches of academic integrity by their peers in a virtual learning environment (Herlyn 2020). Similarly, cheating has been reported as widespread in Canadian secondary schools (Thomson, 2020).

Computer applications such as LitCharts, Spark Notes, Slader, and Photomath have made cheating much easier. Photomath, for example, scans a mathematics problem and offers a step-by-step guide on how to solve it. Unfortunately, although intended as 'teaching tools', there is nothing to stop these applications from being used in nefarious ways.

The implications of cheating have been summarised succinctly by Steve Saldin, a faculty member at the University of Idaho. 'One student with a pattern of cheating is an ethical problem for that student. Multiple students with a pattern of cheating devalues any grade or degree they might be receiving. When cheating spreads to many students in many programmes and schools, degrees and grades cease to provide a measure of an individual's preparedness for a profession or position. And perhaps even more importantly, it suggests a society that blindly accepts any means to an end as a given' (cited in Newton, 2020).

\section{Improving Remote Schooling}

Even a cursory review of online resources will yield a wide range of suggestions and strategies for improving remote schooling. In this section, I will offer three recommendations: increase access and quality, prioritise a culture of care, and accelerate, do not remediate.

\section{Increase Access and Quality}

Virtually every country either has a constitutional guarantee to education or does not have a constitutional guarantee but has ensured that right through an independent statute. Each country has constructed laws around education as a fundamental right of citizens, at least until the age of adulthood. 
If schooling is virtual, then, students must be provided a laptop or tablet and a working internet connection (Mehta, 2020).

If every student has an electronic device and reliable access to the internet, and if teachers have experience and training in how to provide high-quality learning experiences online, remote schooling can be extremely effective. In the past several months, individual states and LEAs in the United States have made a Herculean effort to distribute devices, connect students to the internet, and place regulations on remote schooling (Dorn et al., 2020). Recently, the city of Philadelphia (USA) has widened free internet eligibility for families with children in school (Mezzacappa, 2020). As part of the UN Sustainable Development Goals (SDGs), world leaders have committed to strive for universal and affordable access to the internet in least developed countries by 2020 , and to ensure that women and men have equal access to basic services, including technology, by 2030. With respect to access, then, goals have been set, strides have been made, but there is a long way to go.

In terms of quality, teachers must understand that remote learning requires a fundamentally different approach to teaching (University of Toronto Libraries, 2021). Because the closing of schools occurred quite rapidly, teachers had little time to plan for teaching remotely. Not surprisingly, then, many teachers continued to teach the way they did in regular classrooms. For the most part this was not successful. Successful teaching within remote schooling requires what may be termed 'assignment-driven instruction.' Examples include 'flipped classrooms' (Barshay. 2020), project-based learning (Mathewson, 2020), and case-based learning (Queen's University Centre for Teaching and Learning, 2021).

In flipped classrooms, students are given one or more questions to answer or problems to solve (the assignment). As 'homework,' which is expected to be completed prior to, rather than after, the face-to-face lesson, students are expected to watch a video or explore material that is related to the question(s) or problem(s). This is referred to as the asynchronous phase of instruction since individual students can engage in the assigned activity at any time. During faceto-face time, also known as the synchronous phase, teachers lead a discussion of the question(s) or ask students how they solved the problem(s). This phase is expected to be highly interactive and with students active engaging with the questions or problems assigned.

In project-based learning, students work in groups to complete assignments that require several days, even weeks, to complete. Within online platforms breakout rooms are used by the groups to work together. In project-based learning, teaching of new content is embedded in the projects themselves. That 
is, learning the content is a means to an end, not an end itself (Lee, 2020). When project-based learning has been successful, teachers report higher student engagement because the projects captivate students' attention and give them the freedom to work through parts of the assignment at their own pace (Mathewson, 2019). In project-based learning, teachers are expected to facilitate, encourage, support, and inspire.

Finally, with case-based learning students engage in discussions of specific scenarios that resemble or typically are real-world examples (i.e., cases). The method is learner-centred with intense interaction between participants as they build their knowledge and work together in groups to examine the case. The instructor's role is that of a facilitator.

The changes required by 'assignment-driven instruction' are not made easily by many teachers. Consequently, professional development is likely to be needed. Students also may have difficulty adjusting to their new roles. These roles include setting goals for themselves, managing their work, asking questions when they need help, and collaborating with peers (Kelly, 2020). Role playing and/or modelling may be useful initially to help students become more comfortable with these new roles.

\section{Prioritise a Culture of Care}

Classrooms that are thriving during the pandemic are ones where teachers have developed strong, positive relationships with their students and built inviting, yet business-like, communities of learning (Heyck-Williams, 2020). For many teachers (and administrators) classroom management is synonymous with classroom control. In virtual classrooms, however, teachers who focus on compliance are struggling without the compulsion that physical schools and classrooms provide (Mehta, 2020).

We have known for some time the importance of the first week or two of school. It is during this time span that students and teachers build relationships, set expectations for learning, and reinforce the routines for behaviour (Sonic Learning, 2020). With remote learning, what happens during the first weeks of school is even more important. This spring I had conversations with two of my granddaughters, ages 13 and 14. Both are in schools that practice totally remote learning. Among the questions I asked them was 'Do you know the students in your class?' The 14-year-old quickly answered 'No.' The 13-year-old said that she only knew those students with whom she worked in breakout groups.

Admittedly, it is not easy to promote a culture of care in virtual classrooms. Nonetheless, it can be done. Some teachers have recreated virtual 
bitmoji classrooms (Katz, 2020). The interactive elements of these classrooms allow students to get to know their virtual classmates. Other teachers use Flipgrid (\#Flipgridfever), a social learning platform that allows teachers to pose questions intended to help students get to know one another and ask students to respond in a video (Mason, 2020). As a final example, a high school in Wisconsin has reorganised itself so that every adult in the building is responsible for 10 to 15 students. Students can call or text these adults as needed - the equivalent of an on-call adult to help them navigate their virtual classes (Mehta, 2020).

\section{Accelerate, Not Remediate}

Earlier, I described two different definitions of learning loss - a 'significant reduction in existing knowledge' vs 'learning less than expected.' I mentioned that the choice of definition leads to quite different strategies for solving the 'learning loss' problem. UNESCO, UNICEF, and the World Bank (2020) asked ministries of education to indicate what approach they would use to limit learning loss in the future. Two of the choices were 'remedial programmes' and 'accelerated programmes.' Across a sample of 135 countries, $43 \%$ chose remedial programmes compared to $19 \%$ choosing accelerated programmes. The results were quite similar across income groups (low, lower-middle, upper-middle, and high). In a more recent study conducted by OECD (2021), 86\% of the countries reported providing remedial measures at the primary school level, $75 \%$ did so at the lower-secondary level, and $73 \%$ at the upper-secondary level.

Unfortunately, based on a great deal of research, remediation is generally not effective (Boatman \& Kane, 2018; Mindsteps, 2017). One explanation is that by focusing on remediation alone, students are constantly facing backwards rather than forwards. The more they are backwards focused, the more they are trying to catch up and keep up simultaneously. Unfortunately, while they are trying to catch up, the curriculum continues to move forward.

Acceleration is an alternative to remediation. Acceleration refers to a wide variety of educational and instructional strategies that are used to advance the learning progress of students who are struggling academically or who have fallen behind, strategies that help these students catch up to their peers as well as perform at the level expected by grade-level learning standards. Acceleration requires that educators adopt the principle of 'less is more, a principle first articulated a quarter-century ago (Cushman, 1995). Acceleration has two requirements: 1) focusing on the 'essentials' of the curriculum and 2) reducing the amount of time spent on review. 
Concerning the first requirement, Mehta (2020) suggests that teams of teachers and administrators could work together to decide what is essential to keep and what can be pared. He argues that we should take a page from the Japanese tidying expert and 'Marie Kondo the curriculum,' discarding the many topics that have accumulated like old souvenirs while retaining essential knowledge and topics that spark joy. Similarly, in describing his recommended teaching strategy, Lee (2020) suggests that we shorten up and focus classes only on critical topics while making the bulk of the material available online in various forms.

With respect to the second requirement, a study conducted by the New Teacher Project (2018) is instructive. In the nearly 1,00o lessons observed, students were working on activities related to class 88 per cent of the time. They met the demands of the assignments 71 per cent of the time, and more than half brought home As and Bs; students only demonstrated mastery of grade-level standards 17 per cent of the time. That gap exists because so few assignments actually gave students a chance to demonstrate grade-level mastery. Of the 180 classroom hours in each core subject - ELA, mathematics, science, and social studies - the study found that students spent 133 hours on assignments that were not grade-appropriate (i.e., appropriate for students in lower grades) and 47 hours on assignments that were grade-appropriate. They concluded that would be the equivalent of more than six months of lost learning time in a single school year.

Finally, the transition to acceleration has implications for assessment and evaluation. Educators and policymakers should rely on Rate of Improvement (ROI) as a key metric when monitoring learning progress. While norms will still be valid and important, growth will be a more significant indicator of student success and risk (Bielinski et al., 2020).

\section{The Future of Education Beyond Covid-19}

'As we muddle through the Covid-19 era yearning for a return to something close to normal, we shouldn't squander this occasion to imagine how much better 'normal' could be' (Christakis, 2020, last para.). Andreas Schleicher, head of education at the OECD, has described the pandemic as creating a 'great moment' for learning (OECD, 2021). Likewise, Michael Fullan and his colleagues have asserted that the pandemic has presented us with an unprecedented opportunity to reimagine and transform education. Fullan, Quinn, Drummy, and Gardner (2020) have argued that we are in Phase 2 of a threephase process. Phase 1 began with the disruption caused by the pandemic, the 
closing of schools, and the rapid shift to remote learning. Phase 2, labelled Transition, concerns the planning for reopening while the pandemic is still creating uncertainty. In Phase 3, labelled Reimagining, we will need to lay out a vision for an educational approach that enables all students to thrive and prepares them with skills to navigate ambiguity and change. Finally, phase 3 will require drawing from the best of traditional approaches, innovative practices, and insights from remote learning to shape new, flexible, agile hybrid learning models. In this section, I will briefly outline four things we should expect to see post-pandemic.

1. The digital divide will close at a much faster rate than it has in the past. Technology will be critical to make systems more resilient and provide a continued educational experience at home and at school (Saavedra, 2021). However, closing the digital divide will not be cheap. It is a challenge for both ministries of education and ministries of finance to define the investment path that is needed in the coming years to provide a minimally decent service for all children and youth. A renewed social contract and a political commitment to invest in what is needed to provide the right opportunities to all is unavoidable (Saavedra, 2021).

2. Educational technology will be an integral component of reimaging schools. However, because education is, at its heart, about human connections - between students, teachers, parents, caregivers, principals, and broader communities - criteria for the selection and use of technology will be established. The World Bank (2O20a, 2020b) has suggested that the selection and use of educational technology should be guided by a clear purpose with a focus on educational objectives; reach all learners; engage an ecosystem of partners; and rigorously and routinely use data to learn what strategies, policies, and programmes are effective in maximising student learning.

3. Parents will be part of the solution. During the pandemic, teachers and families have navigated the dynamics of a new world in which parents have a front-row seat to their children's education. Instead of school being a black box, parents can watch their children and their children's teachers every minute of the day if they choose to do so. Parents have come to a new understanding of what they can do to support their children's education and the immense influence that teachers have in the lives of children. In a reimagined education world, parents, teachers, and authorities must cooperate and reach a balance to minimise negative health and education impacts (Arundel, 2020b). 
4. We must prepare for future shocks by building back better. It is not only imperative that we recover from the pandemic but that we use this experience to become better prepared for future crises. The Covid-19 pandemic is not the first crisis to affect education, nor will it be the last. What is meant by 'building back better?' Schools should be better prepared to switch easily between face-to-face and remote learning as needed. Teachers must be better equipped to manage a wide range of IT devices in the event of a future lockdown. Curricula must be sufficiently flexible to be delivered in person or online. The future education system must not be subject to lost learning during the next crisis affecting education. We must be prepared! As we prepare for future shocks, we would be wise to consult the Inter-agency Network for Education in Emergencies (inee.org). The mission of the Network, which has 20 years of experience from which to draw, is to ensure the right to a quality, safe, and relevant education for all who live in emergency and crisis contexts through prevention, preparedness, response, and recovery.

As we exit the pandemic, we would be wise to attend to Andreas Schleicher's perspective on the future of education. Schleicher, Special Advisor on Educational Policy for the Secretary-General, has suggested that 'countries need to use the momentum to reconfigure learning environments to educate learners for their future, not our past. [...] Effective learning out of school during the pandemic placed much greater demands on autonomy, capacity for independent learning, executive functioning, and self-monitoring. The plans to return to school need to focus on more intentional efforts to cultivate those essential skills among all students' (OECD, 2021, p. 5). 


\section{References}

Adams, R. (2021, February 8). Covid hits exam-taking and poorer pupils worst, study finds. The Guardian. https://www.theguardian.com/education/2021/feb/o8/covid-hits-exam-taking-poorerpupils-worst-england-study-finds Arundel, K. (2020a, October 19). 3 COVID-19 education trends set to persist post-pandemic. K12 Dive. https://www.k12dive.com/news/education-trends-to-continue-post-pandemic/586911/ Arundel, K. (2020b, November 17). 3 ways K-12 schools can evolve post-pandemic. K12 Dive. https:// www.k12dive.com/news/how-k-12-schools-can-be-better-evolve-post-pandemic-covid-19/588965/ Asim, S., Carvalho, S. F., \& Gera, R. (2020, June 3). Learning equity during the coronavirus: Experiences from Africa. https://blogs.worldbank.org/education/learning-equity-during-coronavirusexperiences-africa

Auxier, B., \& Anderson, M. (2020, September 10). As schools close due to the coronavirus, some U. S. students face a digital 'homework gap'. https://www.pewresearch.org/fact-tank/2020/o9/10/59-of-u-sparents-with-lower-incomes-say-their-child-may-face-digital-obstacles-in-schoolwork/ Beane, L., \& Shearer, A. (2020, October 9). Will COVID lockdowns hurt your child's social development. https://theconversation.com/will-covid-lockdowns-hurt-your-childs-socialdevelopment-3-different-theories-suggest-theyll-probably-be-ok-137248

Bielinski, J., Brown, R., \& Wagner, K. (2020, August). COVID slide: Research on learning loss \& recommendations to close the gap. https://f.hubspotusercontent2o.net/hubfs/5196620/covid-19-slidewhitepaper.pdf

Boatman, A., \& Kane, T. J. (2018, December 16). Why we need to rethink remediation. https://www. chronicle.com/article/why-we-need-to-rethink-remediation/

Christakis, E. (2020, December). School wasn't so great before COVID, either. https://www.theatlantic. com/magazine/archive/2020/12/school-wasnt-so-great-before-covid-either/616923/

CTV News. (2021, February 7). Unexcused absences up in EPSB schools in first 3 months of school year compared to last year. https://edmonton.ctvnews.ca/unexcused-absences-up-in-epsb-schools-in-first3-months-of-school-year-compared-to-last-year-1.5299602

Cushman, K. (1995, April 11). Less is more: The secret of being essential. http://essentialschools.org/ horace-issues/less-is-more-the-secret-of-being-essential/

Dodd, H., Lester, K., \& Cartwright-Hatton, S. (2020, May 14). Why children need to play with their friends as soon as they can. https://thesector.com.au/2020/05/14/why-children-need-to-play-withtheir-friends-as-soon-as-they-can/

Donnelly, R., \& Patrinos, H. A. (2020, December 8). Is the COVID-10 slide in education real? https:// blogs.worldbank.org/education/covid-19-slide-education-real Donnelly, R., \& Patrinos, H. A. (2021, May 14). Learning loss during COVID-19: An early systematic review. https://www.researchsquare.com/article/rs-518655/v1

Dorn, E., Hancock, B., Sarakatsannis, J., \& Viruleg, E. (2020). COVID-19 and learning loss disparities grow and students need help. https://www.mckinsey.com/industries/public-and-social- 
sector/our-insights/covid-19-and-learning-loss-disparities-grow-and-students-need-help Dorn, E., Panier F., Probst, N., \& Sarakatsannis, J. (2020, August 31). Back to school: A framework for remote and hybrid learning amid COVID-19. https://www.mckinsey.com/industries/public-andsocial-sector/our-insights/back-to-school-a-framework-for-remote-and-hybrid-learning-amidcovid-19

Ferguson, D. (2021, February 6). They are scared to try new things: How is home school impacting young children? https://www.theguardian.com/lifeandstyle/2021/feb/o6/they-are-scared-to-try-newthings-how-is-home-school-impacting-young-children Fleming, N. (2021, January 23). After Covid, will digital learning be the new normal? https://www. theguardian.com/education/2021/jan/23/after-covid-will-digital-learning-be-the-new-normal Fullan, M., Quinn, J., Drummy, M., \& Gardner M. (2020). Education reimagined: The future of learning. https://edudownloads.azureedge.net/msdownloads/Microsoft-EducationReimagined-Paper.pdf Getchell, A. (2020, October 27). The 'COVID slide': Study shows math, reading skills no deteriorating in upper elementary students. https://www.masslive.com/coronavirus/2020/10/the-covid-slide-studyshows-math-reading-skills-now-deteriorating-in-upper-elementary-students.html Giannini, S., \& Albrectsen, A-B. (2020, March 31). Covid-19 closures around the world will hit girls hardest. https://en.unesco.org/news/covid-19-school-closures-around-world-will-hit-girls-hardest Goldstein, D., \& Shapiro, E. (2020, July 29). Teachers are wary of returning to class, and online instruction too. https://www.nytimes.com/2020/o7/29/us/teacher-union-school-reopeningcoronavirus.html

Gray, P (2020, August 3). Survey reveals children coped well with school closure. Psychology Today. https://www.psychologytoday.com/gb/blog/freedom-learn/202008/survey-reveals-children-copedwell-school-closure

Herlyn, J. (2020, October 25). Academic integrity suffers in age of COVID-19, distance learning. Inkling News. https://www.inklingsnews.com/opinions/2020/10/25/academic-integrity-suffers-in-age-ofcovid-19-distance-learning/

Hess, A. J. (2021, January 5). UNICEF executive director: Covid has created a global education emergency. https://www.cnbc.com/2021/01/05/unicef-exec-director-covid-has-created-a-globaleducation-emergency.html

Heyboer, K. (2020, December 3). About $25 \%$ of kids in this N. J. school district are ditching remote learning every day, superintendent says. https://www.nj.com/education/2020/12/about-25-of-kids-inthis-nj-school-district-are-ditching-remote-learning-every-day-superintendent-says.html Heyck-Williams, J. (2020, June 5). Schools as communities of care. https://www.nextgenlearning.org/ articles/schools-as-communities-of-care

Hodges, C. Moore, S., Lockee, B., Trust, T., \& Bond, A. (2020, March 27). The difference between emergency remote teaching and online learning. https://er.educause.edu/articles/2020/3/the-

difference-between-emergency-remote-teaching-and-online-learning. Junio, D. R. (2020, April 15). Digital divide in the time of COVID-19. https://cs.unu.edu/news/news/ digital-divide-covid-19.html 
Kamentz, A. (2020, September 24). School attendance in the COVID era: What counts as present? https://www.npr.org/2020/o9/24/909638343/school-attendance-in-the-covid-era-what-counts-aspresent

Katz, N. (2020, August 3). Teachers are creating virtual bitmoji classrooms - Cute and helpful too! https://www.weareteachers.com/virtual-bitmoji-classroom/

Kelly, M. L. (2020, December 28). Schools face a massive challenge to make up for learning lost during the pandemic. https://www.npr.org/2020/12/28/950814131/schools-face-a-massive-challenge-to-makeup-for-learning-lost-during-the-pandemi?fbclid=IwAR3jgyYj1iq6kvO2iJihfRFZoFLK9v54ZqGAnDKLf40AQ2ooeM2UOzH-hQ

Khan, J. (2020, June 30). Generation lockdown: a third of children and young people experience increased mental health difficulties. https://www.barnardos.org.uk/news/generation-lockdown-thirdchildren-and-young-people-experience-increased-mental-health

Korman, H. T. N., O'Keefe, B., \& Repka, M. (2020, October 21). Missing in the margins: Estimating the scale of the COVID-19 attendance crisis. https://bellwethereducation.org/publication/missingmargins-estimating-scale-covid-19-attendance-crisis

Kuhfeld, M., Lewis, K., Meyer, P., \& Tarasawa, B. (2020, November) Comparability analysis of remote and in-person MAP Growth testing in fall 2020. https://www.nwea.org/content/uploads/2020/11/ Technical-brief-Comparability-analysis-of-remote-and-inperson-MAP-Growth-testing-in-fall-2020NOV2020.pdf

Kuhfeld, M., \& Tarasawa, B. (2020, April). The COVID-19 slide: What summer learning loss can tell us about the potential impact of school closures on student academic achievement. https://www.nwea.org/ content/uploads/2020/05/Collaborative-Brief_Covid19-Slide-APR20.pdf

Kuhfeld, M., Soland, J., Tarasawa, B., Johnson, A., Ruzek, E., \& Lewis, K. (2020, December 3). How is COVID-19 student learning? Initial findings from fall 2020. https://www.brookings.edu/blog/browncenter-chalkboard/2020/12/o3/how-is-covid-19-affecting-student-learning/

Lake, R., \& Makori, A. (2020, June 16). The digital divide among students during COVID-19: Who has access? Who doesn't? https://www.crpe.org/thelens/digital-divide-among-students-during-covid-19who-has-access-who-doesnt

Lee, C. (2020, December 29). All I want for Christmas is an awesome new curriculum. https:// arstechnica.com/science/2020/12/all-i-want-for-christmas-is-an-awesome-new-curriculum/ Levin, D. (2020, May 20). In a world 'so upside down', the virus is taking a toll on young people's mental health. https://www.nytimes.com/2020/05/20/us/coronavirus-young-people-emotional-toll.html Lieberman, M. (2020, October 16). 5 things you need to know about student absences during COVID-19. https://www.edweek.org/leadership/5-things-you-need-to-know-about-studentabsences-during-covid-19/2020/10

Ludlam, B. (2021, January 12). The 5 types of remote learner. https://www.tes.com/news/5-typesremote-learner

Mason, J. (2020, July 27). 15 ways to virtually welcome kids back to school. https://www.weareteachers. com/ways-to-welcome-kids-virtually/ 
Mathewson, T. G. (2019, May 8). Project-based learning boosts student engagement, understanding. https://hechingerreport.org/project-based-learning-boosts-student-engagement-understanding/ Mathewson, T. G. (2020, July 1). Project-based learning get its moment during the coronavirus. https:// hechingerreport.org/project-based-learning-gets-its-moment-during-the-coronavirus/ Mehta, J. (2020, December 27). Make schools more human. https://www.acesconnection.com/blog/ make-schools-more-human-nytimes-com Mezzacappa, D. (2020, December 10). Philadelphia to widen eligibility for free internet access for students. https://philadelphia.chalkbeat.org/2020/12/10/22168135/philadelphia-to-widen-eligibilityfor-free-internet-access-for-students Mindsteps. (2017, August 16). Why remediation is keeping your students behind. https://mindstepsinc. com/2017/o8/remediation-keeping-students-behind/

Maldonado, J. E., \& de Witte, K. (2021, July 21). The effect of school closure on standardized student test outcomes. https://bera-journals.onlinelibrary.wiley.com/doi/10.1002/berj.3754

Newton, D. (2020, August 7). Another problem with shifting education online: cheating. https:// hechingerreport.org/another-problem-with-shifting-education-online-cheating/ OECD. (2021). The state of school education: One year into the COVID pandemic. https://www.oecd. org/education/state-of-school-education-one-year-into-COVID.htm Queen's University Centre for Teaching and Learning. (2021). What is case-based learning? https:// www.queensu.ca/ctl/resources/instructional-strategies/case-based-learning Reimers, F. (2021). Learning from a pandemic: The impact of COVID-19 on education around the world. In F. Reimers (Ed.), Primary and secondary education during COVID-19 (pp. 1-18). Springer. Research Group, Azim Premji Foundation. (2021). Loss of learning during the pandemic. https:// azimpremjiuniversity.edu.in/SitePages/pdf/Field_Studies_Loss_of_Learning_during_the_Pandemic.pdf Ritz, D., O'Hare, G., \& Burgess, M. (2020). The hidden impact of COVID-19 on child protection and wellbeing. Global Alliance. https://www.socialserviceworkforce.org/resources/hidden-impact-covid19-child-protection-and-wellbeing?lang=es

Roderick, M. (1993). The path to dropping out: Evidence for intervention. Auburn House. Saavedra, J. (2021, January 5). A silent and unequal education crisis. And the seeds for its solution. https://blogs.worldbank.org/education/silent-and-unequal-education-crisis-and-seeds-itssolution?cid=SHR_BlogSiteShare_EN_EXT

Sonic Learning. (2020). Why the first two weeks of school are so important. https://soniclearning.com. au/first-two-weeks-school-important/

The New Teacher Project. (2018). The opportunity myth. https://opportunitymyth.tntp.org/theweight-of-wasted-time Tomkins, A. (2020, December 4). Schools are noticing a big increase in F grades. https://www.poynter. org/reporting-editing/2020/schools-are-noticing-a-big-increase-in-f-grades/ Turner, C. (2020, December 1). New report offers clearest picture yet of pandemic impact on student learning. https://www.kut.org/education/2020-12-01/new-report-offers-clearest-picture-yet-ofpandemic-impact-on-student-learning 
UNESCO, UNICEF, and the World Bank. (2020). What have we learnt? Overview of findings from a survey of Ministries of Education on national responses to COVID-19. http://tcg.uis.unesco.org/covidsurvey-r2-infographics/

University of Toronto Libraries. (2021). Digital pedagogy: A guide for librarians, faculty, and students. https://guides.library.utoronto.ca/digitalpedagogy van Dyjk, J. A. G. M. (2020). Closing the digital divide: The role of digital technologies on social development, well-being of all and the approach of the Covid-19 pandemic. https://www.un.org/ development/desa/dspd/wp-content/uploads/sites/22/2020/o7/Closing-the-Digital-Divide-by-JanA.G.M-van-Dijk-.pdf World Bank. (2020a, December 2). Realizing the future of learning: From learning poverty to learning for everyone, everywhere. https://www.worldbank.org/en/topic/education/publication/realizingfuture-of-learning-from-learning-poverty-to-learning-for-everyone-everywhere World Bank. (2020b, December 2). Reimagining human connections: Technology and innovation in education at the World Bank. https://www.worldbank.org/en/topic/edutech/publication/reimagininghuman-connections-technology-and-innovation-in-education-at-world-bank

\section{Biographical note}

Lorin W. Anderson, PhD, is a Carolina Distinguished Professor Emeritus at the University of South Carolina. Having published his first research article in 1975, he has conducted research on the school experiences of marginalized and disenfranchised children throughout the world for almost a half century. He currently serves as the President of the International Academy of Education. 